\title{
Purification and Anticholinesterase Sensitivity of Cholinesterase Extracted from Liver Tissue of Puntius Javanicus
}

\author{
Mohd Khalizan Sabullah ${ }^{1,2}$, Mohd Yunus Abd. Shukor ${ }^{1}$, Nor Aripin Shamaan ${ }^{3}$, Ariff Khalid ${ }^{4}$, Azlan Jualang Ganzau ${ }^{5}$, \\ Mohd Rosni Sulaiman², Hussain Jirangon ${ }^{1}$ and Siti Aqlima Ahmad ${ }^{*}$ \\ ${ }^{1}$ Department of Biochemistry, Faculty of Biotechnology and Biomolecular Sciences, Universiti Putra Malaysia, UPM 43400 \\ Serdang, Selangor, Malaysia \\ ${ }^{2}$ School of Food Science and Nutrition, Universiti Malaysia Sabah, Jalan UMS, 88400, Kota Kinabalu, Sabah, Malaysia \\ ${ }^{3}$ Faculty of Medicine and Health Sciences, Universiti Sains Islam Malaysia, 13th Floor, Menara B, Persiaran MPAJ, Jalan \\ Pandan Utama, Pandan Indah, 55100 Kuala Lumpur, Malaysia \\ ${ }^{4}$ Biomedical Science Program, Faculty of Biomedicine and Health, Asia Metropolitan University, 43200 Cheras, Selangor, \\ Malaysia \\ ${ }^{5}$ School of Science and Technology, Universiti Malaysia Sabah, Jalan UMS, 88400, Kota Kinabalu, Sabah, Malaysia \\ *For Correspondence: aqlima@upm.edu.my; aqlimaahmad@gmail.com
}

\begin{abstract}
The purification of a soluble cholinesterase (ChE) from Puntius javanicus liver using affinity chromatography was studied. Affinity matrix was synthesised through the cooling system of ligands procainamide to epoxy-activated Sephacryl 6B and purification process was performed using calibrated flow rate at $0.2 \mathrm{~mL} / \mathrm{min}$. Non-denaturing electrophoresis condition was employed and the single band native form of $\mathrm{ChE}$ was detected at $66.267 \mathrm{kDa}$ after being stained with commasie brilliant blue. ChE detection was performed using gel filtration; ZORBAX column attached to the HPLC with the flow rate of 1 $\mathrm{mL} / \mathrm{min}$. Only a single peak was detected at the retention time of 3.720. From the assay evaluation, the final purified ChE procedure displayed the highest sensitivity of detecting the anticholinesterase namely mercury, copper, malaoxon and carbofuran compared to the impure $\mathrm{ChE}$ and the results were further discussed in detail to the potential application of ChE from $P$. javanicus as a biomarker for those toxicants. (C) 2015 Friends Science Publishers
\end{abstract}

Keywords: Purification; Cholinesterase; Puntius Javanicus; Anticholinesterase

\section{Introduction}

The liver is the primary target for the accumulation of metabolites especially for the regulation of protein metabolism, glycogen deposition, toxicant degradation and detoxification (Charlton, 1996; Berg et al., 2002; Ferrari et al., 2007; Nyakudya et al., 2014). Detoxifying enzymes such as glutathione S-transferase, glutathione peroxidase and cholinesterase play a major role in the degradation or biotransformation of toxic to non-toxic compounds (Holovská et al., 2005; Cho and Kong, 2007; Ramsey et al., 2010; Nicolet et al., 2003).

Cholinesterase is an enzyme in the group of serine hydrolases that falls broadly into two functionally and structurally identical, yet different enzymes and distributions known as acetylcholinesterase (AChE) and butyrylcholinesterase (BuChE). Both enzymes can be distinguished based on their own substrate specificities, which are acetylcholine (ACh) for AChE and butyrylcholine
(BuCh) for BuChE (Principato et al., 1989; Barbosa et al., 2001; Pohanka et al., 2011; Romani et al., 2011). BuChE is also known as pseudocholinesterase as its capability to hydrolyse both $\mathrm{ACh}$ and $\mathrm{BuCh}$ at different frequencies (Forget et al., 2002; Khan et al., 2008). It has been shown that $\mathrm{BuChE}$ works as a co-regulator for choligernic activity (Giacobini, 2003). Previous studies mentioned that BuChE detoxifies xenobiotic compounds before they reach to AChE at physiologically important target sites (Tougu, 2001; Çokugra, 2003; Nicolet et al., 2003; Gandahi et al., 2013). BuChE is predominantly synthesised in the liver tissue (Santarpia et al., 2013).

Utilisation of $\mathrm{ChE}$ as a biosensor tool is well known (Fulton and Key, 2001; Rao, 2006; Aker et al., 2008). However, previous studies had mentioned that different species exhibited various individual sensitivity results (Kuca et al., 2005; Gbaye et al., 2012; Santarpia et al., 2013) especially fish, which happens to be a preferred tool for the early detection of contaminant existence (Oliveira et al., 2007; Sabullah et al., 2014). However, more data are

To cite this paper: Sabullah, M.K., M.Y.A. Shukor, N.A. Shamaan, A. Khalid, A.J. Ganzau, M.R. Sulaiman, H. Jirangon and S.A. Ahmad, 2015. Purification and anticholinesterase sensitivity of cholinesterase extracted from liver tissue of Puntius Javanicus. Int. J. Agric. Biol., 17: 1025-1030 
required to identify any alternative sources of biosensors that are rapid and sensitive to toxicant especially pesticides and heavy metals contamination.

To obtain a reliable result, purification is needed to increase the sensitivity of ChE to react with the toxicant efficiently. Thus, the objective in this study were: 1) to isolate $\mathrm{ChE}$ from the liver tissue of $P$. javanicus through several purification procedures, 2) to measure the molecular weight of purified ChE based on SDS PAGE and HPLC analysis, and 3) to compare the remaining activity of crude and purified $\mathrm{ChE}$ after treated with toxicant such insecticides and metal ion to prove the sentitive for detection purposes.

\section{Materials and Methods}

\section{Extraction and Purification}

Specimen Preparation: Live Puntius javanicus was brought from Aquaculture Development Centre, Bukit Tinggi, Pahang, Malaysia to laboratory and acclimatised for 15 days with fully aerated and chlorine-free tap water. Water was changed two times per week to ensure water cleanness. Prior the experiment, the fish were not fed for 24 $\mathrm{h}$ to minimise the dietary effects. The fish were killed by immersing it in a box of ice for approximately 30 minutes. The liver was dissected and weighed. Mortar and pestle were first used to crush the liver to facilitate the homogenization process. The extraction process was performed using Ultra Turax homogeniser with $0.1 \mathrm{M}$ sodium phosphate buffer, $\mathrm{pH} 7.5$, containing crushed liver at the ratio of 1:4 (w (sample)/v (buffer)). The crude extract was then ultracentrifuged at $100,000 \times \mathrm{g}$ for $1 \mathrm{~h}$ at $4^{\circ} \mathrm{C}$. The supernatant was collected and stored at $-25^{\circ} \mathrm{C}$.

Procainamide-sephacrayl 6B synthetization: Procainamide-based affinity matrix was synthesised based on the method of Ralston et al. (1983) with slight modification from Son et al. (2002). Sephacryl 6B (50 mL settled gel) was washed with 10 volumes of deionised water using a sintered glass tunnel as recommended by the manufacturer, the Sigma Chemical Company (Poole, UK), sucked dry to a wet cake, then suspended in a volume of 0.6 $\mathrm{M} \mathrm{NaOH}$ containing $50 \mathrm{mM}$ sodium borohydrate (Sigma, St. Louis, USA) and stirred. A volume of 1,4-butanediol diglycidyl ether (Sigma, St. Louis, USA) was slowly added with constant stirring and left overnight at room temperature. Epoxy activated sephacryl waswashed with 10 volumes of deionised water and finally washed using one volume of acetone to completely remove the bioxirane group. The activated gel slurry was washed with distilled water and further washed using 10 volumes of $0.1 \mathrm{M}$ sodium acetate buffer $(\mathrm{pH}$ 4.5) $0.012 \mathrm{M}$ sodium borate buffer ( $\mathrm{pH} \mathrm{10)}$ and 10 volumes of deionised water. The gel slurry was then transferred onto a coupling buffer of $12 \mathrm{mM}$ borate buffer ( $\mathrm{pH} 11.0$ ) containing $0.2 \mathrm{M}$ of procainamide (Sigma, St. Louis, USA) and the $\mathrm{pH}$ of the mixture was adjusted by the addition of $1.0 \mathrm{M} \mathrm{NaOH}$, which was then incubated for $96 \mathrm{~h}$ at room temperature on an orbital shaker. A volume of 1.0 ethanolamine $(\mathrm{pH} 9.0)$ was used to block all of the remaining active groups on the amine-reactive supports of the gel. The mixture was shaken for $6 \mathrm{~h}$ at room temperature. Finally, the gel was washed with 10 volumes of $1.0 \mathrm{M} \mathrm{NaCl}$ followed by $10 \mathrm{~L}$ of deionised water. The gel was then immersed in $30 \%$ of ethanol and stored at $4{ }^{\circ} \mathrm{C}$.

Purification of $\mathrm{ChE}$ using affinity procainamide-based chromatography: The affinity matrix was packed in a column $(0.9 \mathrm{~cm}$ diameter $)$ and allowed to sink to obtain a bed height of $5 \mathrm{~cm}$. The matrix was first washed with 10 column volumes of washing buffer; $20 \mathrm{mM}$ sodium phosphate buffer, $\mathrm{pH} 7.5$, to clean and calibrate the flow rate at $0.2 \mathrm{~mL} / \mathrm{min}$. The supernatant was directly loaded onto the column. After all of the supernatant has been dissolved in the matrix, 3 batch volumes of washing buffer were loaded, followed by the collection of $1 \mathrm{~mL}$ fractions using microcentrifuge tubes and kept on ice. Then, the elution buffer; $20 \mathrm{mM}$ sodium phosphate buffer containing $100 \mathrm{mM}$ sodium chloride, $\mathrm{pH} 7.5$, was applied onto the matrix. The elution phase was continued using a series of elution buffers with $\mathrm{NaCl}$ concentration sranging from $0.2 \mathrm{M}$ to $1.0 \mathrm{M}$. ChE activity (Ellman et al., 1961) and protein content determination (Bradford, 1976) was carried out for all the fractions collected. Fractions that displayed high $\mathrm{ChE}$ activity were then pooled. The purified samples were concentrated and desalted using VivaSpin ${ }^{\circledR}$ tubes at $5000 \times$ $\mathrm{g}$ for $10 \mathrm{~min}$ at $4^{\circ} \mathrm{C}$. The dialysed purified $\mathrm{ChE}$ was stored at $-25^{\circ} \mathrm{C}$ until subsequently used.

\section{Purity and Molecular Weight Determination}

Gel electrophoresis: Native-PAGE was carried by following the method of Laemmli (1970) which included the preparation $4 \%$ stacking polyacrylamide gels and $10 \%$ resolving polyacrylamide gels followed by polymerisation using the addition of N, N, N', N'tetramethylethylenediamine (TEMED) and $10 \%$ of ammonium persulfate (APS). The crude extract, supernatant and concentrated purified $P$. javanicus $\mathrm{ChE}$ were run through the gel. Each protein sample was dissolved in sample buffer containing 0.2 M Tris buffer ( $\mathrm{pH} 6.8$ ), 10\% (w/v) SDS, $20 \%$ (w/v) glycerol, $0.05 \%$ (w/v) bromphenol blue at the ratio of 5:1 (v/v). Broad range of molecular weight (MW) was chosen, containing myosin, $\beta$ galactosidase, BSA, ovalbumin, carbonic anhydrase, soybean trypsin inhibitor, lysozyme and aprotinin with MW of 202.403, 114.802, 73.058, 47.891, 34.111, 27.046, 17.014 and $6.026 \mathrm{kDa}$, respectively (Bio-Rad, UK). The prepared samples and protein markers were loaded in to each well and electrophoresis was performed in a Mini Protean 3 system (Bio-Rad, UK) at a constant current of $16 \mathrm{~mA}$ until the dye front reached the resolving gel $(10 \%$ acrylamide) and then at $25 \mathrm{~mA}$ until the bromophenol dye reached the bottom of the gel. At the end of the process, the 
resolving gel was stained using commasie brilliant blue. The stained gel was then visualised using calibrated G-800 densitometer (Bio-Rad, UK). Retention factor was calculated based on the migration of protein per the migration of bromophenol blue.

HPLC Detection: Purified $\mathrm{ChE}$ and broad range molecular weight standard marker (myosin, $202.403 \mathrm{kDa} ; \beta$ galactosidase, $114.802 \mathrm{kDa}$; BSA, $73.058 \mathrm{kDa}$; ovalbumin, $47.891 \mathrm{kDa}$; carbonic anhydrase, $34.111 \mathrm{kDa}$; soybean trypsin inhibitor, $27.046 \mathrm{kDa}$; lysozyme, $17.014 \mathrm{kDa}$; aprotinin, $6.026 \mathrm{kDa}$ ) were injected into the ZORBAX GF250 gel filtration column that was attached to the HPLC and the eluted protein was then monitored using an HPLC UV detector at a fixed wavelength of $280 \mathrm{~nm}$. Degassed mobile phase containing $0.2 \mathrm{M}$ sodium phosphate buffer and $0.2 \mathrm{M}$ $\mathrm{KCl}$ with added $1 \mathrm{mM} \mathrm{NaN} \mathrm{Nas}_{3}$ as a bacteriosatic agent was used and the flow rate was maintained at $0.5 \mathrm{~mL} / \mathrm{min}$. Each protein molecular weight was plotted versus the retention time (RT) on a semilog scale and the purified $\mathrm{ChE}$ molecular weight was estimated through interpolation of this standard curve.

\section{Sensitivity Improvement Study}

$P$. javanicus $\mathrm{ChE}$; the supernatant and purified $\mathrm{ChE}$ were tested by exposure to $10 \mathrm{mg} / \mathrm{L}$ concentration of mercury, copper, malaoxon and carbofuran using $1.0 \mathrm{mM}$ butyrylthiocholine iodide as the specific substrate of the test. The absorbance was read from 0 to $10 \mathrm{~min}$ at the wavelength of $405 \mathrm{~nm}$. Inhibition were calculated based on remaining percentage activity compared to untreated (control) $\mathrm{ChE}$.

\section{Statistical Analysis}

The data reported in the Fig. 4 and Table 1 were averages of triplicate observations $(n=3)$. The data were subjected to determined their diferrences at the level of $\mathrm{p}<0.05$ using Student T-Test and One-Way Analysis of Variance (ANOVA) based on Tukey post-hoc analyses. All of statistical analyses in this study were automatically calculated using GraphPad Prism version 5.0 (GraphPad Software, California, USA [http://www.graphpad.com/]).

\section{Results}

\section{Purification and Molecular Mass Determination}

The purification profile of $P$. javanicus $\mathrm{ChE}$ and protein concentrations are displayed in Fig. 1. Two peaks of $\mathrm{ChE}$ were obtained with increasing salt concentration, where the first peak was eluted at $200 \mathrm{mM}$ (corresponding to fractions 14 th to 16th) and the second peak was at $500 \mathrm{mM}$ (corresponding to fractions 31st to 34th). The highest peak was pooled for subsequent use. ChE was purified to about 100.813 purification folds with $17.593 \%$ total recovery compared to supernatant with the purification fold of 2

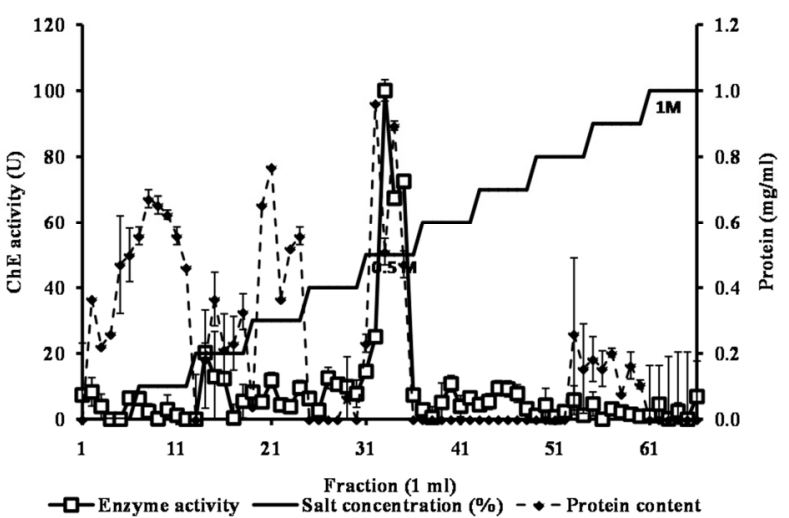

Fig. 1: The purification profile of $\mathrm{BChE}$ from liver tissue of $P$. javanicus
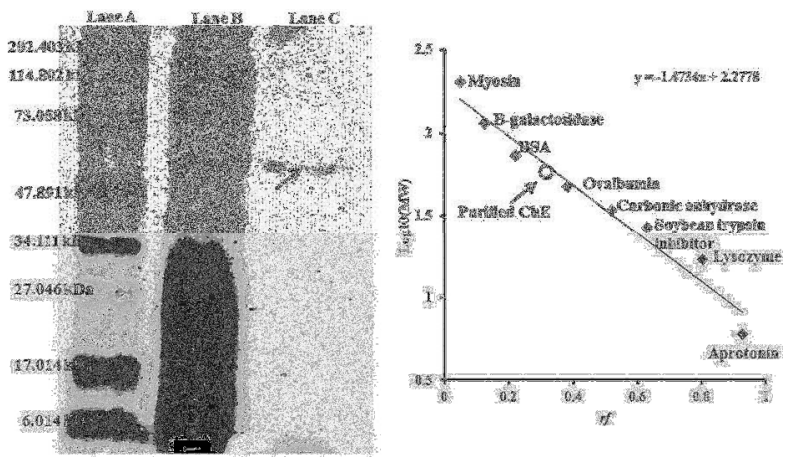

Fig. 2: Non-denaturing polyacrylamide gel electrophoresis (Native-PAGE) of purified ChE from P. javanicus in a $10 \%$ polyacrylamide gel.

Lane A, broad range molecular weight proteins. Lane B, Supernatant. Lane $\mathrm{C}$, protein was recovered from procainamide-sephacrayl $6 \mathrm{~B}$ affinity column. Each protein from the gel were detected by commasie brilliant blue staining. Molecular weight of purified $\mathrm{ChE}$ from $P$. javanicus estimated from broad range molecular weight calibration plot was $66.267 \mathrm{kDa}$ as indicated by an arrow

(Table 1). The non-reducing-PAGE analysis showed a single protein band for $\mathrm{ChE}$ sample that was resolved in $10 \%$ polyacrylamide gel at lane $\mathrm{C}$ after being stained by commasie blue (Fig. 2). The molecular mass of the native form of $P$. javanicus $\mathrm{ChE}$ was estimated by interpolating the molecular weight of the standard proteins and displayed a relatively distinctive $66.267 \mathrm{kDa}$ protein of the purified ChE. HPLC analysis showed the single peak that was detected at the RT of $3.72 \mathrm{~min}$, while the molecular mass of ChE was $69.715 \mathrm{kDa}$. Statistical analysis using Student's ttest showed no significant difference for both molecular weight with triplicate data $(\mathrm{p}>0.05)$.

\section{Inhibition Study}

ChE from $P$. javanicus was tested by incubating in three different toxicants namely copper, malaoxon and carbofuran with the final concentration of $10 \mathrm{mg} / \mathrm{L}$. Based on ANOVA, the results showed that both sample were significantly 
Table 1: Purification table of ChE from the liver tissue of P. Javanicus

\begin{tabular}{llllll}
\hline Procedure & Total Activity (U) & Total Protein (mg) & Specific Activity (Umg $\left.{ }^{-1}\right)$ & Purification factor & Recovery (\%) \\
\hline Crude extract & $1429.412^{* *}$ & 107.796 & 13.273 & 1 & 100 \\
Supernatant & $1137.794^{* *}$ & 42.779 & 26.597 & 2.004 & 79.599 \\
Purified (Procainamide-Sephacrayl 6B) & 251.471 & 0.1879 & 1338.67 & 100.813 & 17.593 \\
\hline
\end{tabular}

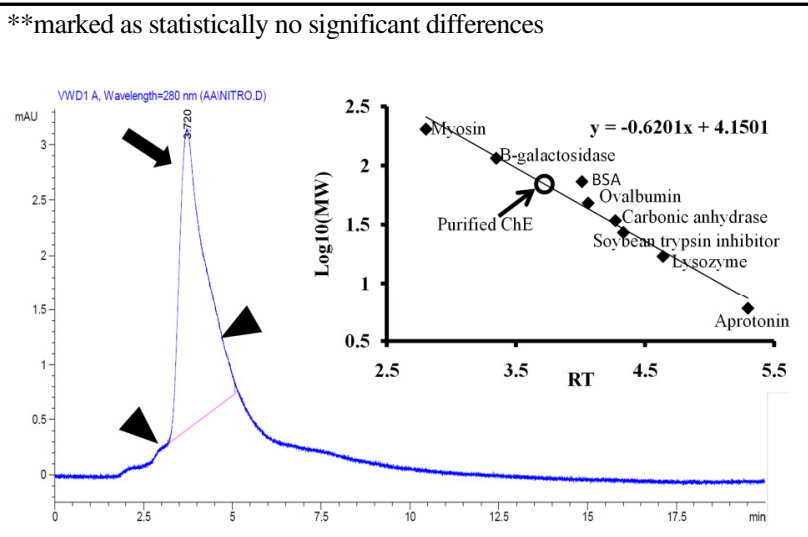

Fig. 3: Profile of purified ChE from P. javanicuson Zorbax GF-250 column attached to HPLC

$\mathrm{ChE}$ was detected at the RT of $3.720 \mathrm{~min}$. The broad range molecular weight marker was injected in the same column and the logarithm data was ploted versus RT. Molecular weight of purified ChE from P. javanicus estimated from broad range molecular weight calibration plot was 69.715 $\mathrm{kDa}$ as indicated by an arrow. Triangles show other protein overlapped with $\mathrm{ChE}$

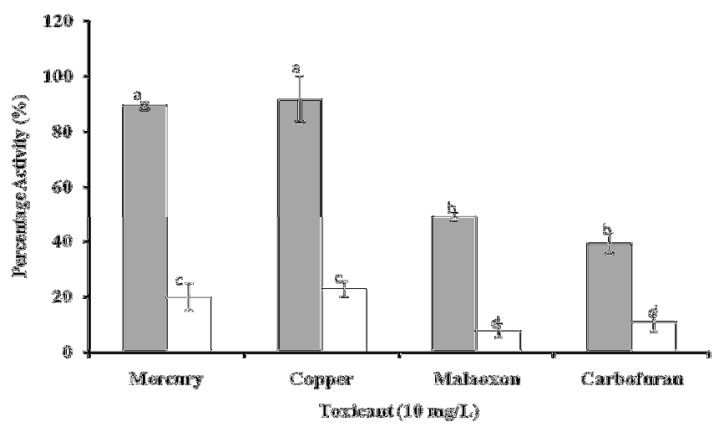

Fig. 4: Comparison the $\mathrm{ChE}$ activity incubated with different toxicants at the concentration of $10 \mathrm{mg} / \mathrm{L}$

The error bar stand for standard deviation of mean $(n=3)$ which all the coeficient value lower than 20\%. Similar letter show no significant different between each mean point $(\mathrm{p}>0.05)$

inhibited by these toxicants $(\mathrm{p}<0.05)$ (Fig. 3). However, the purified sample displayed the highest inhibition, where the activity was reduced to $19.97,22.82,7.93$ and $11.14 \%$ after being treated by mercury, copper, malaoxon and carbofuran, respectively. In comparison, impure $\mathrm{ChE}$ the activity was only reduced to $50 \%$. This study proved that the purified $\mathrm{ChE}$ is more sensitive compared to the impure $\mathrm{ChE}$.

\section{Discussion}

ChE from $P$. javanicus was purified through their basic biospecific interaction with an immobilized procainamide ligand. Previous researches have reported the use of procainamide-based affinity chromatography to purify $\mathrm{ChE}$ from various samples (Forget et al., 2002; Li and Han, 2002; Salles et al., 2006; Tham et al., 2009; Ralph et al., 2011). This affinity matrix was selected due to the isolation of targeted molecule from the abudance of foreign protein which can be purified using high recovery and fold in single step through a specific binding of $\mathrm{ChE}$ bound to the matrix and selectively removed under elution phase by the increase of ionic strength using high salt concentration.

Native-PAGE was carried out to evaluate the efficiency of the purification processes. The results displayed the obvious differences between purification stages with large amounts of foreign proteins being removed until a single band was left after being purified using Procainamide-Sephacrayl 6B. This proved the purification ability of the matrix to isolate $\mathrm{ChE}$ from the liver tissue of $P$. javanicus. ChE exists mostly in various native forms such as two molecular forms in Corbicula fluminea (Mora et al., 1999) and Pacu serum (Salles et al., 2006), three molecular forms in rat (Andres et al., 1990) and cotton aphid ( $\mathrm{Li}$ and Han, 2002) while curimbata serum showed four $\mathrm{ChE}$ bands (Salles et al., 2006). In contrast, results with the purified ChE from $P$. javanicus obtained from non-denaturing PAGE showed only one major protein band after staining with commasie brilliant blue, suggesting a major molecular form of $\mathrm{ChE}$ in our purified sample. However, HPLC analysis showed several small peaks with undetected RT and perhaps, the detected single peak (marked with arrow) was being over lapped with other proteins (marked with triangles) (Fig 3).

Protein purification is required to accurately study the biochemical functions, molecular weight determination, identification and structure of the targeted protein or individual analysis (Berg et al., 2002). The purified protein canthen be used for other purposes such as food processing and drug development. In this study, purification was done carried out to increase the sensitivity of ChE towards toxicants by eleminating foreign proteins that interfere with enzyme action. This interference means that the toxicants are not binding or inhibiting the $\mathrm{ChE}$, but instead bind to other protein through various interactions. Previous studies also reported purified $\mathrm{ChE}$ from various samples to study the inhibition characteristics of toxicant ( $\mathrm{Li}$ and Han, 2002; Hsiao et al., 2004; Yang et al., 2013).

Amino acid residue is the main factor for the binding of toxicant either at the active or allosteric site of $\mathrm{ChE}$. Heavy metals such as mercury and copper are capable of 
inhibiting $\mathrm{ChE}$ by interacting with the negatively charged amino acids such as aspartate or imidazole group of histidine, or cleavage of disulfide bond that leads structural changes (Masson et al., 1996; Najimi et al., 1997; Abdelhamid et al., 2007; Frasco et al., 2008). Mercury and copper both caused low inhibition of unpurified $\mathrm{ChE}$ due to their capability to bind with other thiol and amino groups in protein (Fig. 4) as mentioned by Letelier et al. (2005), but, malaoxon and carbofuran showed higher inhibition rates with slight difference compared to the tested pure $\mathrm{ChE}$. This result indicated that malthion and carbofuran are selective inhibitors with greater affinity to bind with the active site of ChE through the process of phosphorylation and carbamoylation that block the metabolisation of substrate (Boublik et al., 2002; Stojan et al., 2008).

\section{Conclusion}

ChE from $P$. Javanicus was successfully purified using Procainamide-Sephacrayl 6B, which was proven by the appearance of single major band on the nondenaturing electrophorotic gel. Purified ChE was also proved to be more sensitive toward toxicants, namely mercury, copper, malaoxon and carbofuran compared to the impure ChE. This means that, the pure ChE can be selected for future studies such as for biomarker development and further characterisation.

\section{Acknowledgement}

This project was supported by the fund (FRGS) from The Malaysia Ministry of Education under the Project Number TF01301C118, The Ministry of Science, Technology and Innovation, Malaysia (MOSTI) under the Project Number 02-01-04-SF1473, MyBrain15 (MyPhD) and Agricultural Developement Center, Bukit Tinggi, Bentong, Pahang, Malaysia.

\section{References}

Abdelhamid, R.F., Y. Obara, Y. Uchida, T. Kohzuma, D.M. Dooley, D.E. Brown and H. Hori, 2007. $\pi-\pi$ interaction between aromatic ring and copper-coordinated His81 imidazole regulates the blue copper active-site structure. J. Biol. Inorg. Chem., 12: 165-173

Aker, W.G., X. Hu, P. Wang and H.M. Hwang, 2008. Comparing the relative toxicity of malathion and malaoxon in blue catfish Ictalurus furcatus. Environ. Toxicol., 23: 548-554

Andres, C., M. el Mourabit, C. Stutz, J. Mark and A. Waksman, 1990. Are soluble and membrane-bound rat brain acetylcholinesterase different? Neurochem. Res., 15: 1065-1072

Barbosa, M., O. Rios, M. Vela'squez, J. Villalobos and J. Ehrmanns, 2001. Acetylcholinesterase and butyrylcholinesterase histochemical activities and tumor cell growth in several brain tumors. Surg. Neurol., 55: 106-112

Berg, J.M., J.L. Tymoczko and L. Stryer, 2002. The purification of proteins is an essential first step in understanding their function. Biochemistry, $5^{\text {th }}$ edition. W.H. Freeman, New York, USA

Boublik, Y., P. Saint-Aguet, A. Lougarre, M. Arnaud, F. Villatte, S. EstradaMondaca and D. Fournier, 2002. Acetylcholinesterase engineering for detection of insecticide residues. Protein Eng., 15: 43-50
Bradford, M.M., 1976. A rapid and sensitive method for the quantitation of microgram quantities of protein utilizing the principle of protein-dye binding. Anal. Biochem., 72: 248-254

Charlton, M.R., 1996. Protein metabolism and liver disease. Baillieres Clin. Endocrinol. Metab., 10: 617-635

Cho, H.Y. and K.H. Kong, 2007. Study on the biochemical characterization of herbicide detoxification enzyme, glutathione S-transferase Biofactors, 30: 281-287

Çokugra, N., 2003. Butyrylcholinesterase: Structure and physiological importance. Review article. Turk. J. Biochem., 28: 54-61

Ellman, G.L., K.D. Courtney, V.J. Andres and R.M. Featherstone, 1961. A new and rapid calometric determination of acetylcholinesterase activity. Biochem. Pharmacol., 7: 88-95

Ferrari, A., A. Venturino and A.M.P. de D'Angelo, 2007. Effects of carbaryl and azinphos methyl on juvenile rainbow trout (Onchorhynchus mykiss) detoxifying enzymes. Pestic. Biochem. Physiol., 88: 134 142

Forget, J., S. Livet and F. Leboulenger, 2002. Partial purification and characterization of acetylcholinesterase (AChE) from the estuarine copepod Eurytemora affinis (Poppe). Comp. Biochem. Physiol. C., 132: 85-92

Frasco, M.F., D. Fournier, F. Carvalho and L. Guilhermino, 2008. Does mercury interact with the inhibitory effect of dichlorvos on Palaemon serratus (Crustacea: Decapoda) cholinesterase? Sci. Total Environ., 404: 88-93

Fulton, M.H. and P.B. Key, 2001. Acetylcholinesterase inhibition in estuarine fish and invertebrates as an indicator of organophosphorus insecticide exposure and effects. Environ. Toxicol. Chem., 20: 37-45

Gandahi, J.A., N.S. Gandahi, P. Yang, X.G. Bian, M.G. Shah, M. Malhi, L.L. Zhang, Q. Zhang and Q. Chen, 2013. Distribution of acetylcholinesterase positive neurons in the oviduct of laying hen Pak. Vet. J., 33: 213-217

Gbaye, O.A., G.J. Holloway and A. Callaghan, 2012. Variation in the sensitivity of Callosobruchus (Coleoptera: Bruchidae) acetylcholinesterase to the organophosphate insecticide malaoxon: effect of species, geographical strain and food type. Pest Manage. Sci., 68: 1265-1271

Giacobini, E., 2003. Cholinesterases: New roles in brain function and in Alzheimer's disease. Neurochem. Res., 28: 515-522

Holovská Jr, K., A. Sobeková, K. Holovská, V. Lenártová, P. Javorskỳ, J. Legáth, L. Legáth and M. Maretta, 2005. Antioxidant and detoxifying enzymes in the liver of rats after subchronic inhalation of the mixture of cyclic hydrocarbons. Exp. Toxicol. Pathol., 56: 377383

Hsiao, Y.M., J.Y. Lai, H.Y. Liao and H.T. Feng, 2004. Purification and characterization of acetylcholinesterase from oriental fruit fly [Bactrocera dorsalis (Hendel)] (Diptera: Tephritidae). J. Agric. Food Chem., 52: 5340-5346

Khan, D., J.F. Gilmer, C.G. Carolan, J.M. Gaynor and S.A. Ryder, 2008. Pharmacological effects of a novel isosorbide-based Butyrylcholinesterase inhibitor. Chem. Biol. Interact., 175: 231-234

Kuca, K. J. Cabal and J. Kassa, 2005. In vitro reactivation of sarin-inhibited brain acetylcholinesterase from different species by various oximes. J. Enzyme Inhibit. Med. Chem., 20: 227-232

Laemmli, U.K., 1970. Cleavage of structural proteins during the assembly of the head of bacteriophage T4. Nature, 227: 680-685

Letelier, M.E., A.M. Lepe, M. Faúndez, J. Salazar, R. Marín, P. Aracena and H. Speisky, 2005. Possible mechanisms underlying copperinduced damage in biological membranes leading to cellular toxicity. Chem. Biol. Interact., 151: 71-82

Li, F. and Z. Han, 2002. Purification and characterization of acetylcholinesterase from cotton aphid (Aphis gossypii Glover) Arch. Insect Biochem. Physiol., 51: 37-45

Masson, P., M.T. Froment, C.F. Bartels and O. Lockridge, 1996. Asp 70 in the peripheral anionic site of human butyrylcholinesterase. Eur. J. Biochem., 235: 36-48

Mora, P., D. Fournier and J.F. Narbonne, 1999. Cholinesterases from the marine mussels Mytilus galloprovincialis Lmk. and M. edulis L. and from the freshwater bivalve Corbicula fluminea Muller. Comp. Biochem. Physiol. C.,122: 353-361 
Nyakudya, T., S. Makaula, N. Mkumla and K. Erlwanger, 2014. Dietary supplementation with coriander (Coriandrum sativum) seed: effect on growth performance, circulating metabolic substrates and lipid profile of the liver and visceral adipose tissue in healthy female rats. Int. J. Agric. Biol., 16: 125-131

Najimi, S., A. Bouhaimi, M. Daubèze, A. Zekhnini, J. Pellerin and J.F. Narbonne, 1997. Use of acetylcholinesterase in Perna perna and Mytilus galloprovincialis as a biomarker of pollution in Agadir Marine Bay (South of Morocco). Bull. Environ. Contam. Toxicol., 58: 901-908

Nicolet, Y., O. Lockridge, P. Masson, J.C. Fontecilla-Camps and F. Nachon, 2003. Crystal structure of human butyrylcholinesterase and of its complexes with substrate and products. J. Biol. Chem., 278: $41141-41147$

Oliveira, M.M., M.V. Silva Filho, V.L. Cunha Bastos, F.C. Fernandes and J. Cunha Bastos, 2007. Brain acetylcholinesterase as a marine pesticide biomarker using Brazilian fishes. Mar. Environ. Res., 63 : 303-312

Pohanka, M., M. Hrabinova, K. Kamil and J.P. Simonato, 2011. Assessment of acetylcholinesterase activity using indoxylacetate and comparison with the standard Ellman's Method. Int. J. Mol. Sci., 12: 2631-2640

Principato, G.B., S. Contenti, V. Talesa, G. Mangabiene, R. Pascolini and G. Rosi, 1989. Propionylcholinesterase from Allobophora caliginosa. Comp. Biochem. Physiol. C.,94: 23-27

Ralph, E.C., L. Xiang, J.R. Cashman and J. Zhang, 2011. His-tag truncated butyrylcholinesterase as a useful construct for in vitro characterization of wild-type and variant butyrylcholinesterases. Protein Express. Purif., 80: 22-27

Ralston, J.S., A.R. Main, B.F. Kilpatrick and A.L. Chasson, 1983. Use of procainamide gels in the purification of human and horse serum cholinesterases. Biochem. J., 211: 243-250

Ramsey, J.S., D.S. Rider, T.K. Walsh, M. De Vos, K.H. Gordon, L. Ponnala, S.L. Macmil, B.A. Roe and G. Jander, 2010. Comparative analysis of detoxification enzymes in Acyrthosiphon pisum and Myzus persicae. Insect Mol. Biol., 19: 155-164
Rao, J.V., 2006. Biochemical alterations in euryhaline fish, Oreochromis mossambicus exposed to sub-lethal concentrations of an organophosphorus insecticide, monocrotophos. Chemosphere, 65: $1814-1820$

Romani, R., R. Galeazzi, G. Rosi, R. Fiorini, I. Pirisinu, A. Ambrosini and G. Zolese, 2011. Anandamide and its congeners inhibit human plasma butyrylcholinesterase. Possible new roles for these endocannabinoids? Biochimie, 93: 1584-1591

Sabullah, M.K., M.R. Sulaiman, M.Y. Shukor, M.A. Syed, N.A. Shamaan, A. Khalid and S.A. Ahmad, 2014. The assessment of cholinesterase from the liver of Puntius javanicus as detection of metal ions. Sci. World J., 2014: Article ID 571094

Salles, J.B., V.L. Cunha Bastos, M.V. Silva Filho, O.L. Machado, C.M. Salles, S. Giovanni de Simone, J. Cunha Bastos, 2006. A novel butyrylcholinesterase from serum of Leporinus macrocephalus, a Neotropical fish. Biochimie, 88: 59-68

Santarpia, L., I. Grandone, F. Contaldo and F. Pasanisi, 2013. Butyrylcholinesterase as a prognostic marker: a review of the literature. J. Cachexia. Sarcopenia. Muscle, 4: 31-39

Son, J.Y., S. Shin, K.H. Choi and K.I Park, 2002. Purification of soluble acetylcholinesterase from Japanese quail brain by affinity chromatography. Int. J. Biochem. Cell Biol., 34: 204-210

Stojan, J., C. Ladurantie, O.R. Siadat, L. Paquereau and D. Fournier, 2008. Evidence for subdomain flexibility in Drosophila melanogaster acetylcholinesterase. Biochemistry, 47: 5599-5607

Tham, L.G., N. Perumal, M.A. Syed, N.A. Shamaan and M.Y. Shukor, 2009. Assessment of Clarias batrachus as a source of acetylcholinesterase (AChE) for the detection of insecticides. $J$. Environ. Biol., 30: 135-138

Tougu, V., 2001. Acetylcholinesterase: Mechanism of catalysis and inhibition. Curr. Med. Chem., 1: 155-170

Yang, Y.X., L.Z. Niu and S.N. Li, 2013. Purification and studies on characteristics of cholinesterases from Daphnia magna. J. Zhejiang Univ. Sci. B., 14: 325-335

(Received 28 November 2014; Accepted 14 January 2015) 